\title{
The Juridical Formulation of Hate Speech Cyber Crime and Its Law Enforcement Implementation
}

\author{
Hadi Ismanto*), Gunarto**) and Sri Endah Wahyuningsih ${ }^{* * *}$ \\ *) Indonesian National Police, E-mail: hadi.pidkorjtg2@gmail.com \\ ${ }^{* *}$ ) Faculty of Law, Universitas Islam Sultan Agung (UNISSULA) Semarang \\ ${ }^{* * *}$ ) Faculty of Law, Universitas Islam Sultan Agung (UNISSULA) Semarang
}

\begin{abstract}
.
The purpose of this paper is to analyze the juridical formulation of Article 28 paragraph (2) and Article 45 paragraph (2) of the ITE Law and the implementation of law enforcement. The method used is normative juridical. The research results obtained that the juridical formulation of Article 28 paragraph (2) in conjunction with Article 45 paragraph (2) of the ITE Law, contains several juridical weaknesses that it does not formulate the qualifications of the offense whether it is "violation" or "crime" law enforcement. The origin of 28 paragraph (2) is proven through a meaningful analysis of the content of the accused's hate speech phrases that actually cause hostility, communal conflicts through the symbolization of religious figures.
\end{abstract}

Keywords: Cybercrime; Enforcement; Formulation; Speech; Hate; Juridical; Law.

\section{Introduction}

The right to freedom of expression is guaranteed by the 1945 Constitution of the Republic of Indonesia as a human right as well as a human right of the people. As the view of Barda Nawawi Arief who argues that "...according to the Preamble to the 1945 Constitution it is not freedom that is wild and aimless...independence and freedom to be achieved is freedom in order or freedom in an atmosphere of legal order which aims to achieve prosperity and social justice and protection of the entire Indonesian nation." 1

The Law of the Republic of Indonesia Number 11 of 2008 concerning Information and Electronic Transactions (hereinafter referred to as ITE LAW) is one of the set of rules that formulates the provision of hate speech as a crime. The ecosystem that underlies the promulgation of the ITE Law is: ${ }^{2}$ maintain, and strengthen national unity and integrity based on statutory regulations for the national interest, (e) the use of Information Technology plays an important role in trade and national economic growth to realize public welfare, (f) the government needs to support the development of Information Technology through legal infrastructure and its regulations so that the use of Information Technology is carried out safely to prevent its misuse by taking into account the religious and socio-cultural values of the Indonesian people. It appears that the development of information technology throughout the world requires a new order in the legal infrastructure to harmonize the dynamics of information technology with the welfare of the Indonesian nation.

${ }^{1}$ Barda Nawawi Arief, 2008, Bunga Rampai Kebijakan Hukum Pidana, Kencana, Jakarta, p. 71

2 ITE Law, Formulation of Considerations 
Hate speech is defined $a^{3}$ 1) hate speech has the effect of degrading human and human dignity; 2 ) hate speech can undermine the principle of a nation and state with Bhinneka Tunggal Ika and protect the diversity of groups; 3) hate speech can take the form of, among others: insults, defamation, blasphemy, unpleasant acts, provocations, incitement, and spreading false news or slander; 4) hate speech can aim to incite and incite hatred against individuals and/or groups in society which are distinguished from the aspects of: ethnicity, race, religion/belief/belief, intergroup, skin color, gender, people with disabilities, and sexual orientation; 5) Hate speech can be done through various media, such as public speeches, banners, banners, social media networks, demonstrations, religious lectures, mass media, and flyers. Meanwhile, public communication that is currently taking place does not only cover the real world, but has shifted and is extensive in the cyber world (Internet). Based on data from the 2020 Police Criminal Investigation Unit, it is explained that cybercrimes are a transformation of crimes that were originally carried out conventionally into crimes using internet-connected technology. The phenomenon that occurs is known as the Firehose of Falsehood, which is a propaganda technique that broadcasts messages in large numbers quickly, repeatedly and without stopping using modern communication technology. The data description shows that in 2019 Hate Speech / SARA showed CT = 247 and CC = 88. While in $2020 \mathrm{CT}=192$ and CC $=47$.illustrates that the crime clearance rate, which is defined as the percentage of the completion of a crime by the police. ${ }^{4}$.

Research related to law enforcement of the ITE Law is explained based on the findings which show that the handling of criminal acts of defamation through social media based on the ITE Law in the community has not been effective. The fact is the increasing number of criminal acts of defamation from year to year, and the modus operandi of the crime. The first obstacle is the search for perpetrators through social media used by defamation facilities, two factors are inadequate facilities and infrastructure, third is the difficulty of revealing evidence, fourth is the amount of budget needed by the police in the evidentiary process, cases using expert witnesses, and the five different legal perspectives of the founding countries of social media 5 . In addition, other facts were found related to research on the implementation of the ITE Law as compiled in the research statement concluding that crime prevention efforts need to be pursued with a policy approach, in the sense that there is integration between criminal and socio-political politics and there is integration between penal and non-penal crime prevention efforts. The obstacle faced by law enforcement officers today is how to catch cybercriminals in relation to the provisions of the applicable criminal law. Law enforcement officers are faced with difficulties in determining the qualifications of crimes given the difficulty of finding evidence. ${ }^{6}$. Other research explains that the implementation of Act No. 11 of 2008 concerning Electronic Information and Transactions related to social media

\footnotetext{
${ }^{3}$ Chief of Police Circular No. 6/X/2015 concerning Hate Speech (SE Hate Speech) ${ }^{4}$ https://sirusa.bps.go.id/sirusa/index.php/indikator/824

5 Satria Ardi Yana, Bambang Tri Bawono, 2020, "Effectiveness of Implementing ITE Laws and Investigations of Damnation through Social Media”, Law Development Journal, Vol 2, No 3 (2020)

6 Didik Sudarmadi, Jawade Hafidz, 2021, "The Policy For Handling Criminal Acts Of Insult/Hate Speech Or Damage Through Internet", Law Development Journal, Vol 3, No 3 ,2021
} 
users in Indonesia is ineffective and even very bad. This is because there are still many social media users in Indonesia who commit acts against the law on social media due to limited knowledge of the ITE Law. In addition, the obedience and public awareness of social media users are generally very low, so this also causes the legal regulations regarding social media users to be ineffective. Legal factors, legal policy factors, facilities or facilities factors, community factors and legal culture factors are factors that influence the enforcement of Act No. 11 of 2008 concerning Information and Electronic Transactions related to social media users in Indonesia. Because these five factors have caused the ineffective implementation of Act No. 11 of 2008 concerning Electronic Information and Transactions ${ }^{7}$.

Based on the background of these problems, the authors examine in more depth the juridical formulation of hate speech in the ITE Law (as Legal Substance or Legal Substance) and case studies of law enforcement (Legal Structure or Legal Structure) from the implementation of article 28 paragraph (2) and article 45 paragraph (2) ITE LAW. The purpose of this article is to analyze the juridical formulation of Article 28 paragraph (2) and Article 45 paragraph (2) of the ITE Law and the implementation of law enforcement.

\section{Research Methods}

The study method in formulating solutions uses a normative juridical approach in a broad and narrow sense. Method use normative juridical, leading researchers to be able to find the truth by using inductive methods and criteria for measuring a fact in accordance with an appropriate legal study. ${ }^{8}$ When discussing the juridical formulation in the PUU provisions related to hate speech, the approach used is normative juridical in a narrow sense. So that the whole of this article is related to the normative juridical method, both in the broad and narrow sense. This research uses a qualitative approach, which is an approach that emphasizes inductive analysis, descriptive analysis, and the study of people's perceptions or opinions. ${ }^{9}$ The research data was collected through observation and secondary data on court decisions. Meanwhile, data analysis uses inductive thinking method through a series of stages ${ }^{10}$ : discovery of legal problems, classification, analysis and conclusions (discovery of rules). Meanwhile, the analysis orientation uses a conceptual approach (Concept Approach) and a statutory approach (Statue Approach).

\section{Results and Discussion}

\footnotetext{
7 Timbul Mangaratua Simbolon and Gunarto, Kebijakan Hukum Pidana Terhadap Tindak Pidana Penghinaan Atau Pencemaran Nama Baik Melalui Internet Di Indonesia Sebagai Cybercrime, Jurnal Daulat Hukum, Vol 1, No 1,2018 http://jurnal.unissula.ac.id/index.php/RH/issue/view/247

${ }^{8}$ Koko Arianto Wardani and Sri Endah Wahyuningsih, "Kebijakan Formulasi Hukum Pidana Mati Terhadap Pelaku Tindak Pidana Korupsi Di Indonesia”, Jurnal Hukum Khaira Ummah, Vol. 12. No. 4 December 2017, p. 953.

${ }^{9}$ Moleong, L.J, 2004, Metodologi Penelitian, Remaja Rosda Karya, Bandung, p. 3

${ }^{10}$ Artidjo Alkostar, 2018, Metode Penelitian Hukum Profetik, FH UII Press, Yogyakarta, p.38
} 
Hate speech covers a wide spectrum, ranging from harsh speech towards others, hate speech, hate incitement, extreme bias, to hate incitement that leads to violence. ${ }^{11}$. The juridical definition is formulated in the ITE Law as follows: ${ }^{12}$ : "everyone is prohibited from knowingly and without rights spreading information aimed at causing hatred or hostility to certain individuals and/or community groups based on ethnicity, religion, race, and inter-group (SARA)".

Office of the High Commissioner for Human Rights (OHCHR) in 2012 to distinguish between speech protected by the right to express opinion and hate speech on social media.

OHCHR recommends three classifications of hate speech, namely (1) the expression of an opinion that must be punishable by a criminal offense; (2) submission of opinions that may be threatened with administrative sanctions or be sued in a civil manner; and (3) the submission of opinions that cannot be threatened with any sanctions but can be handled with other approaches through government policies.

The submission of an opinion that must be punishable by a criminal offense is incitement to commit genocide, incitement to violence, and incitement to hate hatred based on the following two international regulations:

(1) Article 20 Paragraph 2 of the International Covenant on Civil and Political Rights (ICCPR) which stipulates that solicitation of hatred against a nation, race, or religion that incites acts of discrimination, hostility, or violence must be prohibited by law.

(2) Article 4 of the International Convention on the Elimination of All Forms of Racial Discrimination (ICERD) which stipulates that each Member State must prohibit all forms of propaganda based on an understanding that seeks to justify or encourage hatred of race and discrimination in any form.

Indonesia has ratified both conventions, in 1999 for ICERD and 2005 for ICCPR. Next, the submission of opinions that can be threatened with administrative sanctions or be sued in a civil manner, or even resolved through restorative justice which focuses on the role of perpetrators and victims in solving problems.

Hate speech that falls into this category is speech that contains hate speech based on: Article 19 Paragraph 3 of the ICCPR which stipulates that the right to express opinions can be limited to protect the rights and reputations of others, state security or public order, public health, or for moral purposes.

Then the expression of opinions that cannot be threatened with any sanctions are words that according to Robert Post, a law professor at Yale Law School in the United States (US) in the book Extreme Speech and Democracy, are simply a form of intolerance and feelings of dislike that a person has. Submission of such an opinion is not appropriate to be regulated in the realm of criminal law. A more appropriate approach is through education and prevention policies, for example by advocating for the healthy use of social media supported by censorship that is more sensitive to indications of hate speech in social media.

11 Devita Putri dalam https://theconversation.com/apakah-semua-ujaran-kebencian-perludipidana-catatan-untuk-revisi-uu-ite-156132, accessed on 8 July 2021

12 Article 28 paragraph (2) of the ITE Law 


\subsection{Hate Speech Cyber Crime Case Position (SARA) ${ }^{13}$}

"It was discovered that on Friday, August 28, 2020 at approximately +05.30 WIB when the witness was at the Balai Bambu Fishing Site, St. Sigorok district. Blado Batang Regency, at that time the witness opened his Facebook account and saw a post from Ali Rocman's facebook account which had been shared by Anisa Nisha Nisha's facebook account, and it was known that in Ali Rocman's post there was a screen capture of the upload display that reads "Habib Luthfi is the name of my neighbor's DOG" by Facebook account user Abul A'la Almaududi then posted it in the facebook group "BERSATUNYA SALAFI AND ASWAJA SUFI".
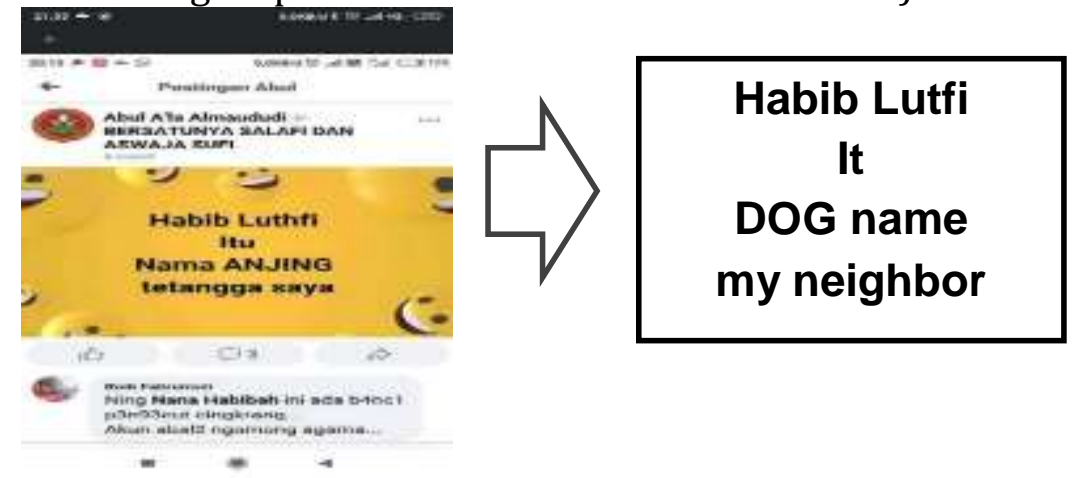

\subsection{Juridical Formulation of the Hate Speech Article (SARA) of the ITE Law}

A juridical formulation is a formulation/statement of criminal provisions which explicitly states the prohibition norm or the command norm. As in this study is Article 28 paragraph (2) of the ITE Law: Article 28 paragraph (2) which is regulated in the ITE Law is formulated as follows:

"(2) Every person intentionally and without rights disseminates information aimed at causing hatred or hostility towards certain individuals and/or community groups based on ethnicity, religion, race, and inter-group (SARA)"

- Juridical Formulation of Article 45 A paragraph (2):

Any person who knowingly and without rights disseminates information aimed at creating feelings of hatred or hostility towards certain individuals and/or community groups based on ethnicity, religion, race, and inter-group (SARA) as referred to in Article 28 paragraph (2) shall be punished with imprisonment for a maximum of 6 (six) years and/or a maximum fine of IDR 1.000.000.000,00 (one billion rupiah)

The explanation in the ITE Law regarding the two articles can be formulated as follows:

- Article 28 paragraph (2) with information: quite clear.

- Article 45A paragraph (2) with information: quite clear.

Based on the understanding of the systematic construction of criminal article 28 paragraph (2) and article 45A paragraph (2) what the author means is a criminal provision that contains a formulation stating the imposition of a criminal offense

13 Minutes of Opinion on Investigation Order Number: SP.Sidik/955/IX/2020/Reskrimsus, dated 28 September 2020 
against a provision containing prohibition norms or orders. ${ }^{14}$. Construction is the arrangement and relationship of words in a sentence or group of words ${ }^{15}$, while systematic means regular according to the system; use the system; in a wellorganized way ${ }^{16}$. Thus, the essence of a criminal article that is systematically constructed contains a juridical formulation: the criminal act (criminal act) and criminal sanctions for the act. In addition, between articles in the PUU which contain criminal provisions, there is a systematic relationship between articles, which are often referred to as the main article and its derivative articles. In this subchapter, the author examines the substantive criminal system contained in the criminal article formulated in Article 28 paragraph (2) and 45A paragraph (2) of the ITE Law. The substantive criminal system is essentially a criminal provision in the legislation under study which is part of the overall criminal system or criminal law system currently in force in the Criminal Code. ${ }^{17}$. Article 28 of the ITE Law regulates illegal content, namely the act of spreading false and misleading news that results in consumer losses in electronic transactions, as well as acts of spreading hatred or hostility based on SARA.

\subsection{Law Enforcement of the Crime of Hate Speech (SARA) ITE Law}

A systematic study of the a quo case, explained that the panel of judges proved through the facts of the juridical construction trial of Article 28 paragraph (2) that the suspect was charged with the following:

- The defendant has been indicted by the Public Prosecutor on a single charge as regulated in Article 45A paragraph (2) jo. Article 28 paragraph (2) of Law of the Republic of Indonesia Number 19 of 2016 concerning Amendments to Law of the Republic of Indonesia Number 11 of 2008 concerning Information and Electronic Transactions, the elements of which are as follows:

- Everyone;

- Intentionally and without rights;

- Disseminate information aimed at causing hatred or hostility to certain individuals and/or community groups based on ethnicity, religion, race and inter-group (SARA) as referred to in Article 28 paragraph (2).

- Proof of "Everyone" Element

The element of each person basically refers to the person who must be responsible for the act or incident that is accused, or at least who the person must be made the defendant in this case, which is in accordance with the rules in the decision of the Supreme Court of the Republic of Indonesia No. 1398 K/Pid/1994 dated June 30,1995 , which states that everyone is anyone who must be made a defendant or everyone as a legal subject (supporting rights and obligations) who can be held accountable for their actions.

The legal subject in this case, has been brought before the trial of a person named Abul A'la Almaududi Bin Alm Arsidi, whose identity has been confirmed

14 Barda Nawawi Arief, 2012, Kebijakan Formulasi Ketentuan Pidana Dalam Peraturan PerundangUndangan, Pustaka Magister, Semarang, p.12

15 Kamus Besar Bahasa Indonesia, 2008, Pusat Bahasa Departemen Pendidikan Nasional, p.822

16 Ibid, p.1495

17 Barda Nawawi Arief, Op.Cit, p.3 
by the person concerned and during the examination process at the trial the Defendant showed an attitude of being able to take responsibility for all his actions. Thus the element of whoever has been proven legally and convincingly.

- Proof of the Element "Intentionally and Without Right"

The legal facts revealed in court, on Wednesday, August 5, 2020, at approximately 23.15 WIB, the Defendant opened and used the Facebook account of Abul A'la Almaududi (owned by the Defendant) then the Defendant made/written the words or sentences "Habib Luthfi is the name of my neighbor's dog." then the Defendant uploaded a post containing the words or sentences mentioned above in the social media facebook group "BERSATUNYA SALAFI AND ASWAJA SUFI".

The sentence "Habib Luthfi is the name of my neighbor's dog" in the Defendant's post can cause conflict in society where Habib Luthfi is the name of one of the Islamic religious scholars / figures because it can be categorized as a form of harassment and insult to Habib Lutfi's person and Muslims.

The defendant posted the sentence publicly with the intention that it could be accessed and seen by many people. Thus this element has been proven.

- Proof of the Element "Distributing information aimed at causing feelings of hatred or hostility towards certain individuals and/or community groups based on ethnicity, religion, race and intergroup (SARA)"

In general, law enforcement on hate speech cases as regulated in Article 28 paragraph (2) of the ITE Law explains that legal events in the cyber (virtual) world can be criminally prosecuted because the legal substance that regulates them is already available. In the law of evidence, the panel of judges proves the elements of the offense charged against the defendant. The a quo case consists of 3 elements: first, "Everyone" the legal basis used by the panel of judges is the decision of the Supreme Court of the Republic of Indonesia No. 1398 K/Pid/1994 dated June 30, 1995 , which states that everyone is anyone who must be made a defendant or everyone as a legal subject (supporting rights and obligations) who can be held accountable for their actions. Second, the element of "intentionally and without rights" was proven through the fact at trial that the Defendant posted the sentence openly with the intention that it could be accessed and seen by many people. Third, the element "Distributing information aimed at causing hatred or hostility to certain individuals and/or community groups based on ethnicity, religion, race and intergroup (SARA)." The law for proving the panel of judges is through an electronic information content approach with an indicator that the defendant is proven to have posted on the Facebook platform hate speech phrases that can trigger communal conflicts and create feelings of hatred or hostility towards certain individuals or groups, especially Muslims themselves, especially if Habib Lutfi is likened to a dog where dogs are unclean animals.

\section{Clossing}

The juridical formulation of Article 28 paragraph (2) in conjunction with Article 45 paragraph (2) of the ITE Law contains several juridical weaknesses. One of them is that the ITE Law (Act No. 11/2008 which has been amended by Act No. $19 / 2016$ ) does not formulate the qualifications for the offense whether it is a 
"violation" or a "crime". The juridical consequences, in the application of the law, have an impact on determining the elements (limits) of trial, assistance and conspiracy that can be punished. The problem is whether article 53 paragraph (1), article 56 and article 88 of the Criminal Code can apply? Article law enforcement the content of hate speech formulated in the elements of Article 28 paragraph (2) is proven through content analysis by experts in the field of Islam and linguists. Basically, the sentence of the accused's hate speech actually caused hostility and communal conflict through the symbolization of religious figures who were insulted and abused by the defendant. The content approach was carried out by the panel of judges with screen capture evidence of the defendant's hate speech posted through the defendant's Facebook platform.

\section{References}

\section{Journals}

[1] Barda Nawawi Arief, "Kebijakan Reformulasi Ancaman Pidana Mati Tindak Pidana Korupsi dalam Peraturan Perundang-Undangan," Jurnal MMH, Jilid 42, 1 Januari 2013

[2] Didik Sudarmadi, Jawade Hafidz, "The Policy For Handling Criminal Acts Of Insult/Hate Speech Or Damage Through Internet", Law Development Journal, Vol3,No3,2021 http://jurnal.unissula.ac.id/index.php/ldj/issue/view/562

[3] Koko Arianto Wardani dan Sri Endah Wahyuningsih, "Kebijakan Formulasi Hukum Pidana Mati Terhadap Pelaku Tindak Pidana Korupsi Di Indonesia", Jurnal Hukum Khaira Ummah, Vol. 12. No. 4 December 2017

[4] Satria Ardi Yana, Bambang Tri Bawono, "Effectiveness of Implementing ITE Laws and Investigations of Damnation through Social Media", Law $\begin{array}{lllll}\text { Development Journal, } & \text { Vol } & 2, & \text { No } & 3,\end{array}$ http://jurnal.unissula.ac.id/index.php/ldj/article/view/11993

[5] Timbul Mangaratua Simbolon and Gunarto, "Kebijakan Hukum Pidana Terhadap Tindak Pidana Penghinaan Atau Pencemaran Nama Baik Melalui Internet Di Indonesia Sebagai Cybercrime", Jurnal Daulat Hukum, Vol 1, No 1, 2018 http://jurnal.unissula.ac.id/index.php/RH/issue/view/247

\section{Books}

[1] Artidjo Alkostar, 2018, Metode Penelitian Hukum Profetik, FH UII Press, Yogyakarta

[2] Barda Nawawi Arief, 2012, Kebijakan Formulasi Ketentuan Pidana Dalam Peraturan Perundang-Undangan, Pustaka Magister, Semarang

[3] Moleong, L.J, 2004, Metodologi Penelitian, Remaja Rosda Karya, Bandung

[4] Sudarto, 1981, Hukum dan Hukum Pidana, Alumni, Bandung.

[5] Kamus Besar Bahasa Indonesia, 2008, Pusat Bahasa Departemen Pendidikan Nasional

\section{Internet}

[1] Devita Putri dalam https://theconversation.com/apakah-semua-ujarankebencian-perlu-dipidana-catatan-untuk-revisi-uu-ite-156132, accessed on 8 July 2021 
[2] https://sirusa.bps.go.id/sirusa/index.php/indikator/824

\section{Regulation}

[1] Chief of Police Circular No. 6/X/2015 concerning Hate Speech (SE Hate Speech) 